\title{
Veterinary Drug Development from Indonesian Herbal Origin: Challenges and Opportunities
}

\author{
Yedi Herdiana $^{1}$, Nasrul Wathoni ${ }^{1}$, Sriwidodo' ${ }^{1}$, K Ketut Mudite Adnyane ${ }^{2}$
}

\author{
${ }^{1}$ Department of Pharmaceutics and Pharmaceutical Technology, Faculty of Pharmacy, Universitas \\ Padjadjaran, Sumedang 45363, Indonesia. \\ ${ }^{2}$ Departement of Anatomy, Physiology, and Pharmacology, Faculty of Veterinary Medicine, Bogor \\ Agricultural University (IPB University), Indonesia.
}
Received: 3 March 2021, Revised: 22 March 2021, Accepted: 27 March 2021, Published: 1 April 2021

\begin{abstract}
Herbal medicine is increasingly being used in human and veterinary medicine to reduce and prevent minor ailments and support conventional treatment using allopathic medicine. The medicinal properties of the plants used in phytotherapy are due to the large number of active compounds found in the plant kingdom. The active compounds extracted from the plant is often equivalent to a synthetic drug according to its therapeutic efficacy; thus, they are used in veterinary medicine, primarily as antibacterial, antimycotic, antiparasitic, disinfect, and immunostimulant.pharmaceutical quality, ensuring safety, specific standards of purity, and consistency. These standards apply throughout the production and formulation process. This review describes the development of herbs that can be used as veterinary drugs with the possibility of dosage form technology. Veterinary dosage forms show great promise for the future of the herbal veterinary delivery system.
\end{abstract}

Keyword: Veterinary drug, herbal medicine, dosage form, drug delivery.

\section{Introduction}

Veterinary medicine is the branch of science that applies medical, surgical, public health, dental, diagnostic, and therapeutic principles to nonhuman animals. Animals provide us with companionship (e.g., Dog and cat), recreation (e., g. Horse), food (e.g., Cattle and pig), and manual labor (whether an elephant carrying $\log$ in Thailand or a hunting dog retrieving a downed pheasant in South Dakota). Just like humans, these animals have received medicines to keep them healthy, and the reasons for producing single-dose veterinary dosage forms are the same as those in humans; to permit delivery of action in a form that is effective, safe, and able to be handled and administered by the end-user $1-3$.

Animal care and animal welfare in rural populations is based on ethnomedical veterinary practice, especially when access to western veterinary products is difficult or too expensive. The cost of using veterinary drugs accounts for more than $50 \%$ of all medical expenses. Synthetic veterinary drugs have adverse side effects, such as drug resistance and increased toxicity in animals due to excessive doses 4 . Side effects of synthetic drugs, such as 
antibiotic residues, cause antibiotic resistance in humans; toxic metabolites remain in the meat 5. Synthetic drug side products are a concern in the long-term use of these drugs. Problems like this have prompted the search for alternatives such as herbal medicines, as they are cheap and safe compared to modern animal health care systems 6 .

Medicinal herbs contain various pharmacologically active ingredients, and each herb has unique combinations and properties 6 . Veterinary herbal medicine can be applied for therapeutic, prophylactic, or diagnostic in animal health care. The use of herbal medicines is considered to have no side effects or minimal side effects, non-narcotic product, available quickly and at an affordable price. Traditional veterinary knowledge consists of a collection of beliefs and practices about animal welfare that involve the use of natural resources [4]. The demand for plant-based drugs is increasing in both human and veterinary medicine [7-9]. Alternative medicine is becoming popular all over the world, and herbal medicine has become one of the most common forms of alternative therapy and complementary therapy and supplements to allopathic medicine [8].

Indonesia is a country that has a wealth of herbs. In ethnopharmacology, many plants are commonly used as medicine in animals 7 . There are great opportunities for herbal development for veterinary, as regulated by Kepmentan No 453/2000 concerning Natural Medicines for Animals. Animal treatment using herbal medicines, according to the government, must be standardized through research. After passing scientific research and testing, herbal medicines must obtain approval from the Ministry of Agriculture or be registered 8. Livestock disease is one of the biggest obstacles in improving the quality of livestock production. Farmers need the best medicine to treat diseases that attack livestock [10].
Like human medicine, pharmacists are expected to design, manufacture and control veterinary drug delivery systems. On the other hand, some drugs or drug formulations may not be suitable for animals. The design and preparation of veterinary drug delivery systems requires consideration and challenges compared to preparations for humans. 3,9,10.

This review provides an overview of the use of herbal medicine in veterinary studies from various studies. Special considerations and developments are needed to change the empirically used preparations into drug delivery systems that are easier to use, stable, and have more benefits. This review provides an overview of the great potential of Indonesian herbs and how to empower them to be more scientific and effective as a herbal medicine veterinary.

\section{Plant Used in Herbal Veterinary}

Herbal drugs usually used in human practice are often utilized in pets, particularly by owners who used such remedies for themselves (6). They are given to companion animals to treat respiratory, skin, urinary, digestive, and cardiovascular affections and to reduce stress; moreover, they are also used to treat some chronic diseases instead of conventional drugs to avoid adverse effects that sometimes could occur as a consequence of a prolonged administration of synthetic drugs. Finally, phytotherapy could represent valuable support to conventional therapies in the case of severe illness. While few studies have been carried out to evaluate the therapeutic efficacy of herbal remedies in companion animals, many studies have been found in the literature relating to the use of plants and plant materials in farm animals (2). 
3. Dosage forms of veterinary herbal medicines herbal medicinal products

Development of the principle of veterinary medicine beneficial response when the body interacts with veterinary drugs. The continued impact of this trait will ultimately have implications such as (i) generating favorable responses such as

The general property of a veterinary drug is that it is not easy to predict the emergence of a

Table. 1 Plant Used in Herbal Veterinary

\begin{tabular}{|c|c|c|c|c|}
\hline Scientific name & Used parts & Use & Species & Reference \\
\hline $\begin{array}{l}\text { Cymbopogon } \\
\text { citratus }\end{array}$ & Leaves & Anthelmintic & $\begin{array}{l}\text { Chicken } \\
\text { poultry }\end{array}$ & 12 \\
\hline \multirow[t]{3}{*}{$\begin{array}{l}\text { Zingiber } \\
\text { officinale } \\
\end{array}$} & $\underline{\text { Rhizome/root }}$ & Antibacterial & $\begin{array}{l}\text { Chicken } \\
\text { poultry }\end{array}$ & 1314 \\
\hline & Rhizome/root & $\underline{\text { Phytobiotics }}$ & $\frac{\text { Chicken }}{\text { poultry }}$ & $\underline{15}$ \\
\hline & Rhizome/root & Wound healing & Mice & 16 \\
\hline \multirow[t]{3}{*}{ Alpinia galanga } & Rhizome/root & Antibacterial & $\frac{\text { Chicken }}{\text { poultry }}$ & $\underline{17,18}$ \\
\hline & $\underline{\text { Rhizome/root }}$ & Phytobiotics & $\frac{\text { Chicken }}{\text { poultry }}$ & $\underline{15}$ \\
\hline & Rhizome/root & Antifungal & Dog & $\underline{19}$ \\
\hline \multirow[t]{3}{*}{$\begin{array}{l}\text { Andrographis } \\
\text { paniculata }\end{array}$} & Leaves & Antibacterial, Imonomodulator & $\begin{array}{l}\text { chicken } \\
\text { poultry }\end{array}$ & $\underline{20}$ \\
\hline & Leaves & Antibacterial & Cow & 2122 \\
\hline & $\underline{\underline{\text { Leaves }}}$ & Hepatoprotector & Mice & $\underline{23}$ \\
\hline$\frac{\text { Tamarindus }}{\text { indica }}$ & $\underline{\text { Fruit }}$ & Weight gain & $\begin{array}{l}\text { Chicken } \\
\text { poultry }\end{array}$ & 24 \\
\hline \multirow{3}{*}{$\begin{array}{l}\text { Curcuma } \\
\text { xantorriza }\end{array}$} & Rhizome/root & Lactasion & Cow & $\underline{25-27}$ \\
\hline & & Hepatoprotector & Chiken Poultry & $\underline{28}$ \\
\hline & & Anthelmintic, Weight gain & Sheep & $\underline{29}$ \\
\hline $\begin{array}{l}\text { Kaempferia } \\
\text { galanga }\end{array}$ & Rhizome/root & Weight gain & Cow & 30 \\
\hline $\begin{array}{l}\text { Piper } \\
\text { retrofractum }\end{array}$ & $\underline{\text { Fruit }}$ & Aphrodisiac & Mice & $\underline{31}$ \\
\hline $\begin{array}{l}\text { Orthosiphon } \\
\text { aristatus }\end{array}$ & $\underline{\text { Herbs }}$ & Diuretic & Cattle & $\underline{31}$ \\
\hline \multirow[t]{2}{*}{ Allium sativum } & $\underline{B u l b s}$ & Weight gain & $\begin{array}{l}\text { Chicken } \\
\text { Poultry }\end{array}$ & $\underline{32}$ \\
\hline & Bulbs & Antibacterial & Cow & $\underline{33}$ \\
\hline Carica papaya & Fruit seeds & Anthelmintic & $\begin{array}{l}\text { Chicken } \\
\text { poultry }\end{array}$ & $\underline{34}$ \\
\hline$\frac{\text { Hibiscus }}{\text { sabdariffa }}$ & $\underline{\text { Leaves }}$ & Immunostimulant & Mice & $\underline{35}$ \\
\hline $\begin{array}{l}\text { Catharanthus } \\
\text { roseus }\end{array}$ & $\underline{\text { Leaves }}$ & Wound healing & $\underline{\text { Mice }}$ & 3637 \\
\hline
\end{tabular}

expectations, (ii) the emergence of new diseases in infected animals due to veterinary drug administration. Other impacts are (iii) causing residual hazards in processed products of animal origin, (iv) causing contamination of the habitat of infected animals. If the effect is in the form of a beneficial response according to the plan, it will not be a problem. However, if the response is in the form of a new disease caused by drugs, and/or it causes residues of 
veterinary drugs and contaminants of animal habitat. The problem will not benefit human life. As a way out of the issues mentioned above, it is time to change the orientation of the management strategy towards a logical and responsible direction [38].

The development of the cito principle has the meaning as soon as possible to bring the drug closer to the target pathological part of the body. However, when the pathological part of the body has recovered, then as soon as possible, the drugs or medical equipment used must be eliminated. The development of the tuto principle has four meanings, namely (i) safe when used as a means of treatment, (ii) safe from the impact of contamination residues on processed animal products, (iii) safe from causing damage to animal habitat, (iv) safe from abuse of animal drugs and veterinary drug abuse. The development of the curare principle has requirements, namely the selection based on the patient's treatment strategy by designing the dose, selecting the type of active ingredient, adjusting the time and method of administration, and determining the dosage form. The development of the jucunde principle has the meaning of having to accommodate animal welfare criteria, including veterinary drug preparations that must not cause pain/hunger, (ii) fear, (iii) unpleasant taste for animals. Another aspect of the jucunde principle is that the activity of administering veterinary drugs must create a sense of security from possible attacks by animal sufferers to make the drug giver comfortable 38

\subsection{Dosage forms of veterinary herbal} medicines herbal medicinal products

Veterinary drug delivery is still rare in research. From a total of more than 8000 research papers focusing on delivering medical, veterinary, and agricultural active ingredients published between 1990 and 2020, only 3\% are focused on veterinary applications, $4 \%$ on agricultural applications, and the rest of $93 \%$ on medical applications [39].
Considerations in making dosage forms in animals, have some of the same pharmaceutical principles. Pharmaceutics is an interdisciplinary science that involves the integration of physical pharmacy, pharmaceutical formulation, manufacturing technology, dispensing pharmacy, and the laws of pharmaceutics [40]. The same factors influence the process of dosage form development and quality control considerations [41-43]. These factors include:

1. The physical and chemical characteristics of the active pharmaceutical ingredient (API) such as:

a. intrinsic solubility (aqueous solubility of the unionized form of the drug);

b. pKa;

c. ability to traverse the biological membrane;

d. stability:

e. in the presence of excipients

f. during manufacture

g. shelf life

h. crystal characteristics (e.g., crystalline habit, particle size, particle shape).

2. The intended use of the dosage form:

a. targeted duration of drug release;

b. stability in the gastrointestinal (GI) tract (orally administered products);

c. ease of administration;

d. limitations on dosage form:

e. size of tablets or capsules or volume of an oral liquid

f. injection volume

g. location of administration (e.g., skin, ophthalmic, ear).

3. Formulation that includes excipients to insure that the product delivers the drug in a manner defined by the pharmacologist/clinical expert.

4. Method of manufacture (based upon drug and intended dosage form characteristics).

Pharmaceutic principles are discussed from the perspective of the design of drug delivery 
systems (dosage forms), the formulation and manufacturing variables influencing in vivo and in vitro product performance, and the product understanding necessary to assure that the dosage form is effective, safe, and stable [41-43].

From an evolutionary perspective, it seems likely that the use of many médicinal plants may hâve derived from the ingestion of rarely eaten or fall-back foods (consumed in periods of major food shortage) with supportive médicinal properties [44]. In many cases below, herbal medicines for veterinary use can be given or prepared in whole herb or herb extracts, as shown in Fig.1

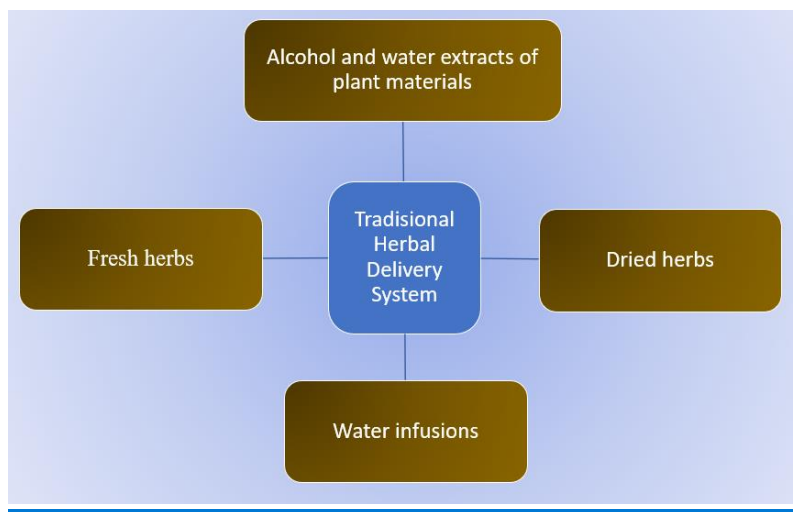

Fig 1. The Use of herbal medicine in veterinary

Although most veterinary dosage forms contain the same drug as human dosage forms, some veterinary preparation includes drugs that are not widely used in humans. 3 . These reasons do not impact the science used to develop such dosage forms, but they heavily impact the outcomes such as the size, shape, volume administered, etc., of the dosage form. Veterinary pharmaceuticals play an important role in human and animal health $[45,46]$.

Dosage forms are how drug molecules or plant parts are delivered to sites of action within the body [47]. The routes for which herbal dosage forms may be administered include oral, rectal, topical, parenteral, respiratory, nasal, ophthalmic, and otic, as shown in Fig 2. Categorizing finished herbal products into dosage forms will help define specific protocols for quality control and stability testing. Herbal medicinal products may be designated as finished, labeled medicinal products containing active ingredients aerial or underground parts of plants, or other plant material, or combinations thereof, whether in the crude state or as plant preparations. Herbal medicines may contain excipients in addition to active ingredients. Medicines containing plant materials combined with chemically defined active substances, including chemically defined, isolated plants, are not considered herbal medicines. Finished herbal products or herbal drug preparations are varied, and various solvents may be used for their extraction, distillation, expression, fractionation, purification, concentration, or fermentation. These include comminuted or powdered herbal drugs, tinctures, extracts, essential oils, expressed juices, and processed exudates. Factor Involved in Deciding route of administration: Concentration of drug needed, the site where drug required, time of action, duration of action, circumstances of action site, safety, and cost [48].

Pharmaceutical quality is an essential ingredient of product safety and requires the product to be manufactured according to specific standards of purity and consistency. These standards apply throughout the production and formulation process. Stability studies ensure that the product retains its potency, efficacy, and safety for the full duration of the shelf-life 2. However, veterinarians and pharmacists must be aware of potential incompatibilities and practices that may interfere with the drug's stability, purity, and potency 3 .

\subsection{Unique aspects Veterinary Dosage Form}

Animal drug dosage forms have their requirements \& characteristics based on the unique aspects of mammal \& avian physiology. Many drugs used in veterinary medicine are not used in human medicine, and therefore, pharmacists may not know their attributes. The 
pharmacist who desires to practice in this area should undertake self-study to learn the chemical, biochemical (metabolism), pharmacological (mechanisms), therapeutic (clinical outcomes), and pharmaceutical (dosage forms) and pharmacokinetic characteristics of these compounds. Some dosage forms are specially designed for animals (e.g., Ear tags, collars, and darts). Most drug delivery systems (including nano-carriers

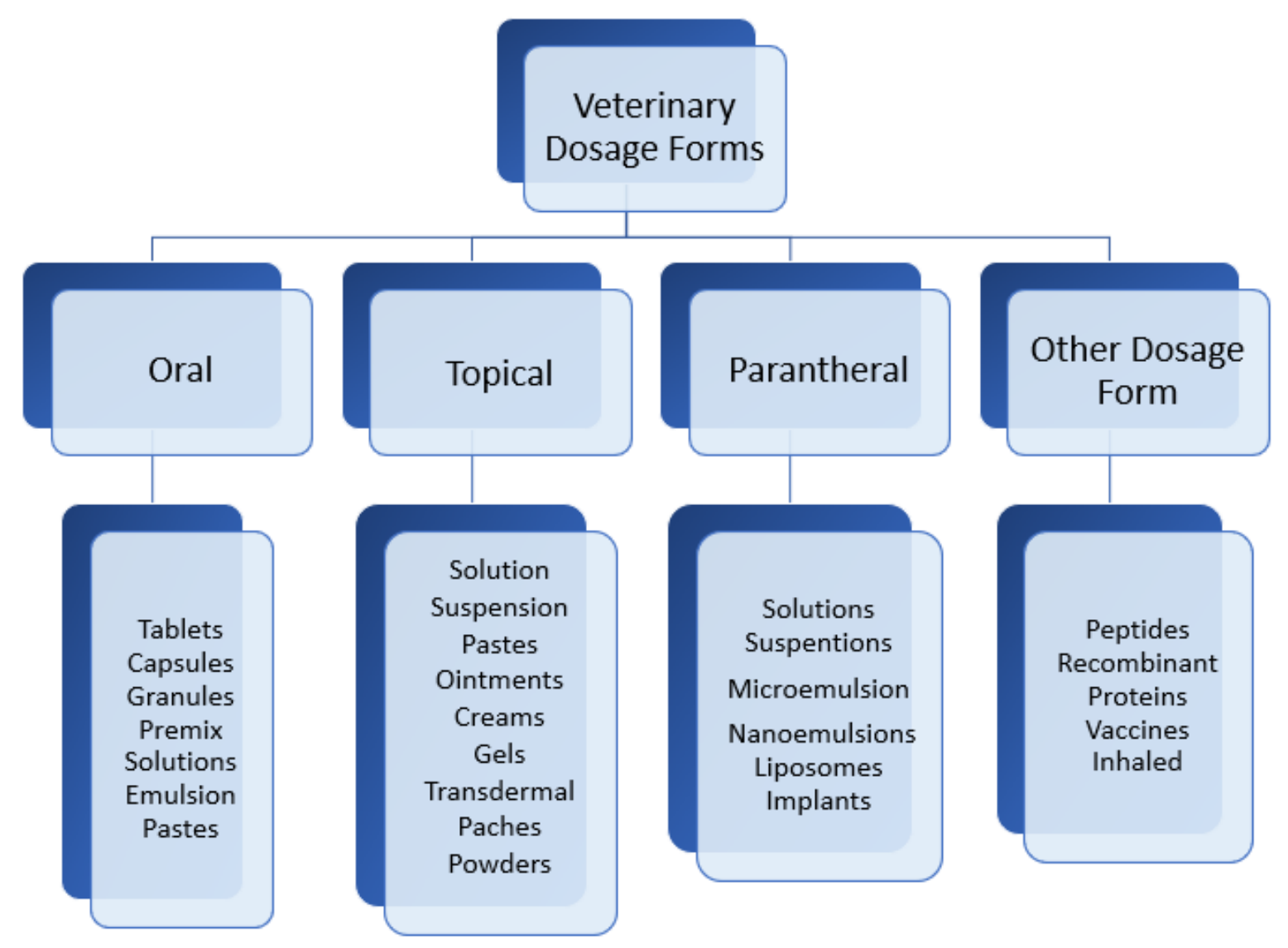

Fig 2 Dosage forms of herbal medicinal products

and controlled drug delivery systems) are common among animals and humans 9.

Flavors that animals prefer to include Dog prefers Beef, Chicken, Cheddar Cheese, Molasses, Peanut Butter, Liver, Raspberry, Strawberry. Cat prefers Tuna, Chicken, Beef, Cheddar Cheese, Peanut Butter, Liver, Butterscotch. Bird prefers Grape, Mandarin Orange, Tutti-Frutti, Molasses, Pina Colada. Horse prefers Apple, Creamy Caramel, Molasses, Licorice, Cherry. Rabbit prefers Banana Ferret prefers Bubble Gum, Molasses. Gerbils prefers Mandarin Orange, Tutti-frutti 9.
In general there are similarities between human and animal preparations, but there are some that are specific to animals 3 .

- medicated powders for administration in drinking water (herd health);

- drenches (a large volume of aqueous suspension or solution containing the API that is pumped into the animal's rumen);

- medicated articles (a formulation intended for administration in feed)

- rumen bolus (a large tablet designed for administration in ruminants and which can provide either immediate drug release or 
remain in the rumen for a prolonged duration of time to provide extended drug release).

\section{Herbal drugs used in veterinary practice}

For veterinary use, quality specifications for veterinary herbal medicines need to be developed. There is a need for validation of traditional claims systems (detailed pharmacognostic, phytochemical, and pharmacological studies, etc.) and evaluation of the safety of plant models for their development and use as veterinary drugs 49 .

Standardization of veterinary herbal medicines is needed to determine their quality, consistency, and reproducibility. This stage is to ensure that one or more of the main phytochemical ingredients of veterinary herbal medicines or other ingredients are present in the specified amount. Quality control is applied for batch-wise consistency, dose uniformity, stability, and to detect contamination/counterfeiting. Identifying the biologically active compounds in herbs is very important for quality control and for determining the dosage of plant-based drugs. When used in small amounts, certain plants are useful as veterinary drugs, while in large quantities they are toxic 49,50.

Standardization of herbal medicines is a complicated process because these medicines contain complex mixtures of different compounds. Thus, the herbs responsible for the medicinal effect are often unknown. Knowledge of the physicochemical properties of herbal medicines, along with other preformulation data, is necessary for the standardization and validation of active constituents. Various chemical, spectroscopic, and biological methods are also employed for the standardization. Some examples include infrared spectroscopy, liquid chromatography, high-performance thin-layer chromatography (HPTLC), nuclear magnetic resonance, mass spectroscopy, etc 51-53.
Good manufacturing practices (GMP) is a system that ensures that the products manufactured are consistently produced are controlled according to quality standards and that they minimize those risks involved in the production that cannot be eliminated through testing of the final product. GMP covers all aspects of production from the starting materials, premises, and equipment to the staff's training, safety measures, and personal hygiene. It also ensures that proper standard operating procedures are followed; the work environment is controlled; quality assurance, packaging, and labeling are done according to the requirements 48,51 .

Currently used for veterinary medicine, many use drugs commonly used in humans. Drug administration is done by adjusting the dose. The proper translation of drug doses from one animal species to another and the translation of animal doses to human doses are both critical to the safety and efficacy of drugs. The equivalence to human doses was calculated using the formula shown in Table 2 54,55.

Table 2 Conversion of human equivalent dose to animal dose 55

\begin{tabular}{|c|c|c|c|}
\hline$\underline{\text { Species }}$ & $\frac{\text { Weight }}{\underline{(\mathrm{kg})}}$ & $\underline{\underline{\mathrm{BSA}}} \underline{\underline{\mathrm{mg} / \mathrm{m} 2)}}$ & $\underline{\underline{\text { factor }}}$ \\
\hline \multicolumn{4}{|l|}{ Human } \\
\hline$\underline{\text { Adult }}$ & $\underline{60}$ & $\underline{1.6}$ & $\underline{37}$ \\
\hline Child & $\underline{20}$ & $\underline{0.8}$ & $\underline{25}$ \\
\hline Baboon & $\underline{12}$ & $\underline{0.6}$ & $\underline{20}$ \\
\hline Dog & $\underline{10}$ & $\underline{0.5}$ & $\underline{20}$ \\
\hline Monkey & $\underline{0.3}$ & $\underline{0.24}$ & $\underline{12}$ \\
\hline$\underline{\text { Rabbit }}$ & $\underline{1.8}$ & $\underline{0.15}$ & $\underline{12}$ \\
\hline Guinea Pig & $\underline{0.4}$ & $\underline{0.05}$ & $\underline{8}$ \\
\hline$\underline{\text { Rat }}$ & $\underline{0.15}$ & $\underline{0.025}$ & $\underline{6}$ \\
\hline$\underline{\text { Hamster }}$ & $\underline{0.008}$ & $\underline{0.02}$ & $\underline{5}$ \\
\hline Mouse & 0.02 & $\underline{0.007}$ & $\underline{3}$ \\
\hline
\end{tabular}

\section{Perspective}

Traditional veterinary knowledge is passed down from generation to generation. The disconnect between traditional veterinary knowledge in the current generation has led to 
its extinction. To overcome the extinction of local wisdom in veterinary medicine, there must be studies that are continuously seeking from various sources. 56,57.

Future developments will apply technology that is currently developing and helps in the world of health by implementing an intelligent drug delivery system. One practical function of nanotechnology in medicine, which is currently being developed, involves using nanoparticles to administer drugs or other constituents to specific cell types 58. Nanoparticles were developed to deliver hormones, antibiotics, genes, anticancer drugs, anti-inflammatory drugs, antigens, and growth factors. The system can be used for target delivery of different cargo molecules to increase drug bioavailability, maintain drug effect on specific target tissues/organs, solubilize drug, and improve drug stability against degradation 39.

The others is developing a drug into a longacting delivery system include reducing dose frequency to improve patient compliance or enhancing the efficiency of therapy and thereby improving the health of the patient. In contrast, in the veterinary field, the major reasons for developing a drug into a long-acting drug delivery system is to minimize animal handling to reduce the stress to animals from repeated administration and to reduce the cost of treatment in terms of money and time spent by the end-user on drug administration. The veterinary area offers opportunities to develop novel controlled-release drug delivery technologies adapted to livestock or companion animal health needs 39 .

The administration of drugs through the skin is a non-invasive, convenient, and comfortable way to administer drugs without trauma or risk of infection This procedure avoids gastric metabolism and the first-pass effect through the liver found in the oral treatment. It also reduces side effects and increases the interval between administrations, thereby facilitating treatment compliance from pet owners (Prausnitz 59)

\section{Conclusion}

The development of veterinary herbal medicine will be a new solution to overcome the challenge of antibiotic resistance to increase animal production. In some cases, it also improves profitability in meat production or meets the safety criteria related to drug residues. Veterinary medicice play a role in restoring animal health, which will have an impact on human welfare. To develop traditional preparations, the latest pharmaceutical knowledge is needed, to make effective and efficient preparations. This development requires special consideration in making veterinary preparations. As in traditional medicine for humans, to be able to progress, it needs special attention for its development from the government, researchers, business. There must be development of veterinary herbal medicines that can be sold at relatively low prices compared to modern medicines. If herbal veterinary medicines lose their advantage over allopathic medicines

\section{References}

1. Kebede, H., Melaku, A. \& Kebede, E. Constraints in animal health service delivery and sustainable improvement alternatives in North Gondar, Ethiopia. Onderstepoort J. Vet. Res. 81, 1-10 (2014).

2. Russoa, R., Autoreb, G. \& Severino, L. Pharmaco-Toxicological Aspects of Herbal Drugs Used in Domestic Animals. Nat. Prod. Commun. 8, (2013).

3. Ramteke, K., Joshi, Sa, Dighe \& Kharat. Veterinary Pharmaceutical Dosage Forms: A Technical Note. Austin Ther. 1, 1-10 (2014).

4. Martínez, G. J. \& Luján, M. C. Medicinal plants used for traditional veterinary in the Sierras de Córdoba (Argentina): An ethnobotanical comparison with human medicinal uses. J. Ethnobiol. Ethnomed. 7, 23 (2011). 
5. Mund, M. D., Khan, U. H., Tahir, U., Mustafa, B. E. \& Fayyaz, A. Antimicrobial drug residues in poultry products and implications on public health: A review. Int. J. Food Prop. 20, 1433-1446 (2017).

6. Gupta, S. et al. Need to Strengthen Herbal Veterinary Sector. Pharma Times 45, 4547 (2013).

7. Kaunang, S. R., Asyiah, I. N. \& Aprilya, S. Etnobotani Pemanfaatan Tumbuhan Secara Tradisional Dalam Pengobatan Hewan Ternak Oleh Masyarakat Using Di Kabupaten Banyuwangi. Indones. J. Biotechnol. Biodivers. 3, 27-32 (2015).

8. Amalia, Z. \& Adisasmito, W. Analysis of Policy Making Factors on The Prohibition of Hormones and Antibiotics Use for Feed as a Public Health Protection. J. Indones. Heal. Policy Adm. 2, 14 (2017).

9. Tiwari, S., Mitkare, S. \& Bhangale, P. Veterinary dosage forms: Review. Int. J. Appl. Pharm. 6, 20-29 (2014).

10. Toutain, P. L. \& Koritz, G. D. Veterinary drug bioequivalence determination. J. Vet. Pharmacol. Ther. 20, 79-90 (1997).

11. Singh, R., S.K.Kotwal \& A.K.Srivastava. Reseach in Veteraninary Herbal Drug. (2002).

12. Iryani, I. et al. Inventory of Anthelmintic Plant use in Livestock at Sub DAS Krueng Simpo Aceh Province. J. Ilm. Peternak. 3, 14-19 (2015).

13. Naprila, Z. H. Pengaruh Penambahan Serbuk Jahe Merah (Zingiber Officinale var.rubrum) dalam Pakan Sebagai Imonomodulator Pada Fase Starter Ayam Broiler Terhadap Ekspresi IG A dan gambaran Hispatologi Ileum Yang Diinfesiksi Salmonella enteritidis. (Universitas Brawijawa, 2019).

14. Widiastuti, D. \& Pramestuti, N. Antimicrobial Test Of Red Ginger Extract (Zingiber Officinale) Against Staphylococcus Aureus. J. Penelit. Kesehat. 5, 43-49 (2018).
15. Edi, D. N. Pemanfaatan Kandungan Bioaktif Tanaman Lokal Untuk Menunjang Produktifitas Ternak Unggas (Ulasan). Briliant J. Ris. dan Konseptual 5, 819 (2020).

16. Sadikim, R. Y., Sandhika, W. \& Saputro, I. D. Pengaruh Pemberian Ekstrak Jahe Merah ( Zingiber officinale var . rubrum ) terhadap Jumlah Sel Makrofag dan Pembuluh Darah pada Luka Bersih Mencit ( Mus musculus ) Jantan ( Penelitian Eksperimental pada Hewan Coba ) ( Effect of Red Ginger [ Zingiber offic. J. Berk. Ilmu Kesehat. Kulit dan Kelamin 30, 121 127 (2018).

17. Hendro, H., Adriani, L. \& Latipudin, D. Pengaruh Pemberian Lengkuas (Alfinia Galanga) Terhadap Kadar Neutrofil dan Limfosit Ayam Broiler. in Peningkatan Produktivitas Sumber Data Peternakan 531-536 (2013).

18. Mulyaningsih, B., Pramono, S. \& Suhardjono, D. Uji toksisitas minyak atsiri jahe (Zinngiber Officinale) sebagai antifilariasis pada hewan uji mencit dan tikus. Berkala Ilmu Kedokteran 31, 71-76 (1999).

19. Hernani, Bunasor, T. K. \& Fitriati. Formula Sabun Transfaran Antijamur dengan Bahan Aktif Ekstrak Lengkuas (Alpinia galanga L.Swartz.). Bul. Penelit. Tanam. Rempah dan Obat 21, 192-205 (2016).

20. Ulfah, M. \& Natsir, M. H. Pemanfaatan Sambiloto, Andrographis panicula Nees, Sebagai Aditif Pakan Untuk Meningkatkan Performan Ayam Pedaging. Encephale 53, 59-65 (2013).

21. Effendi, M. H. Aktivitas Antibakterial Ekstrak Herba Sambiloto (Andrographis panicula Nees) Terhadap Bakteri Staphylococcus Asal Susu Sapi Perah Penderita Mastitis. J. Penelit. Med. Eksanta 8, (2009).

22. Nugroho, A., Rahardiningtyas, E., Wicaksono Putro, D. B. \& Wianto, R. 
Pengaruh Ekstrak Daun Sambiloto (Andrographis paniculata Ness.) terhadap Daya Bunuh Bakteri Leptospira sp. Media Penelit. dan Pengemb. Kesehat. 26, 77-84 (2016).

23. Sagita, A. Pengaruh Ekstrak Andrographis paniculata ( Sambiloto ) Terhadap Kadar Serum Glutamat Oksaloasetat Transaminase Pada Tikus Wistar Yang diberi Paracetamol. Pharmacology (Universitas Diponegoro, 2006).

24. Imran, M. Pengaruh Pemberian Asam Jawa ( Tamarindus indica L ) Sebagai Acidifier Terhadap Pertambahan Berat Badan dan Income Over Feeder. (UIN Alaudin Makassar, 2020).

25. Sulistyowati, E., Badarina, I. \& Santoso, U. Suplementasi Level Temulawak (Curcuma xanthorrhiza, Roxb) yang Berbeda dalam Konsentrat pada Sapi Frisien Holland Laktasi: Pengaruhnya terhadap Total Digestible Nutrient (TDN) Ransum. J. Sain Peternak. Indones. 5, 2026 (2010).

26. Setiadi, D., Rudy Hartanto \& Harjanti, D. W. Pengaruh Pemberian Suplemen Tepung Temulawak (Curcuma Xantorriza Roxb) Terhadap Konsumsi Protein Kasar, Kecernaan Protein Kasar dan Produksi Susu Pada Sapi Perah Laktasi. J. Ilm. Peternak. Terpadu 8, 133-140 (2020).

27. Sunaryati, Muktiani, A. \& Ahmadi, J. Suplementasi Temulawak (Curcuma Xanthoriza) dan ZN Proteinat Terhadap Konsumsi Produksi Energi Susu Pada Sapi Perah. Anim. Agric. J. 2, 168-174 (2013).

28. Candra, A. A. Aktivitas Hepatoprotektor Temulawak pada Ayam yang Diinduksi Pemberian Parasetamol Hepatoprotector Activity of Curcuma in Chickens was Induced By Paracetamol. J. Penelit. Pertan. Terap. 13, 137-143 (2013).

29. Nizma, A., Humaidah, N. \& Suryanto, D. Pengaruh Tingkat Pemberian Temulawak (Curcuma Xantoriza) Sebagai Obat Cacing Herbal Terhadap Jumlah Telur Cacing
Haemonchus Contortus dan Pertambahan Berat Badan Domba. J. Peternak. 1, 1-6 (2015).

30. Nurcholis, Salamony, S. M. \& Muchlis, D. Efektifitas Pelatihan Pemanfaatan Jamu Sebagai Suplemen Bagi Sapi Bagi Peternak di Kampung Mimi Baru Distrik Jagebob. Musamus Devot. J. 1, 7-12 (2019).

31. Erjon, Sriwahyuni, Y., Lely, N. \& Sari, E. R. Efek Pemberian Ekstrak Cabe Jawa (Piper Retrofractum Vahl) Terhadap Peningkatan Libido Mencit Putih Jantan. FITOFARMAKA J. Ilm. Farm. 10, 133139 (2020).

32. Nuningtyas, Y. F. Pengaruh Penambahan Tepung Bawang Putih (Allium Sativum) Sebagai Aditif Terhadap Penampilan Produksi Ayam Pedaging. J Ternak Trop. 15, 65-73 (2014).

33. Naionoe, T. A., Tahuk, P. K. \& Purwantiningsih, T. I. Penggunaan Ekstrak Bawang Putih (Allium sativum) Sebagai Bahan Alami Celup Puting terhadap Kualitas Mikrobiologis Susu Sapi Segar. J. Anim. Sci. 4, 50-51 (2020).

34. Yowi, M. R. K. \& Moenek, D. Y. J. A. Daya Membunuh Cacing Ekstrak Biji Pepaya ( Carica Papaya ) Pada Ayam Buras. Partner 16, 11-15 (2006).

35. Besung, I. N. K. Effect of C. extract enhance phagocytic capacity of peritoneal macrophages in Balb/C mice infected with Salmonella thypi ). Bul. Vet. Udayana 3, 71-78 (2011).

36. Puspita Dewi, I., Damriyasa, I. \& Anom Dada, I. Bioaktivitas Ekstrak Daun Tapak Dara (Catharanthus Roseus) Terhadap Periode Epitelisasi Dalam Proses Penyembuhan Luka Pada Tikus Wistar. Indones. Med. Veterinus 2, 58-75 (2013).

37. Fernandes, M., Dada, I. K. A. \& Damriyasa, I. M. Bioaktivitas Ekstrak Daun Tapak Dara (Catharantus Roseus) Terhadap Kecepatan Angiogenesis Dalam 
Proses Penyembuhan Luka Pada Tikus Wistar. Indones. Med. Veterinus 2, (2013).

38. Lazuardi, M. Implementasi dan Pengembangan Prinsip Maximum Asclepiades Pada Penggunaan Obat Hewan dan Alat Kesehatan Hewan. 1-20 (2010).

39. Cerbu, C., Kah, M., White, J. C., Astete, C. E. \& Sabliov, C. M. Fate of Biodegradable Engineered Nanoparticles Used in Veterinary Medicine as Delivery Systems from a One Health Perspective. Molecules 26, (2021).

40. Hunter, R. P., Shryock, T. R., Cox, B. R., Butler, R. M. \& Hammelman, J. E. Overview of the animal health drug development and registration process: An industry perspective. Future Med. Chem. 3, 881-886 (2011).

41. Riviere, J. E. \& Papich, M. G. Veterinary Pharmacology and Therapeutics. (2018).

42. Rathbone, M. J. \& Gurny, R. Controlled Release Veterinary Drug Delivery. (2000).

43. Ahmed, I. \& Kasraian, K. Pharmaceutical challenges in veterinary product development. Adv. Drug Deliv. Rev. 54, 871-882 (2002).

44. Huffman, M. A. Animal origins of herbal medicine. Des sources du savoir aux médicaments du Futur 31-42 (2016). doi:10.4000/books.irdeditions.7199

45. Stafford, E. G. Highlighting the role of veterinary pharmacists in zoonotic diseases including COVID-19. J. Am. Pharm. Assoc. 84-90, (2020).

46. Shrestha, K., Acharya, K. P. \& Shrestha, S. One health: The interface between veterinary and human health. Int. J. One Heal. 4, 8-14 (2018).

47. Sriharitha, J, P. \& Swaroop, H. A Review on Nanoparticles in Targeted Drug Delivery System. Res. Rev. J. Mater. Sci. 04, 1-6 (2017).

48. Swarbrick, J. Development and Formulation of Veterinary Dosage Forms. Comprehensive Organometallic Chemistry
(Marcell Dekker Inc, 1998). doi:10.1016/b978-008046518-0.09004-8

49. Rastogi, S., Pandey, M. K., Prakash, J., Sharma, A. \& Singh, G. N. Veterinary herbal medicines in India. Pharmacogn. Rev. 9, 155-163 (2015).

50. P, S. Veterinary Drug Development from Indian Herbal Origin: Challenges and Opportunities. J. Anal. Pharm. Res. 3, 2-4 (2016).

51. Kunle. Standardization of herbal medicines - A review. Int. J. Biodivers. Conserv. 4, (2012).

52. Bijauliya, R. K. \& Pradesh, U. A Comprehensive Review On Standardization Of Herbal Drugs. Int. J. Pharm. Sci. Res. 8, 4930-4949 (2017).

53. Nikam, P. H., Kareparamban, J., Jadhav, A. \& Kadam, V. Future trends in standardization of herbal drugs. J. Appl. Pharm. Sci. 2, 38-44 (2012).

54. Nair, A. \& Jacob, S. A simple practice guide for dose conversion between animals and human. J. Basic Clin. Pharm. 7, 27 (2016).

55. Shin, J., Seol, I. \& Son, C. Interpretation of Animal Dose and Human Equivalent Dose for Drug Development. J. Korean Orient. Med. 31, 1-7 (2010).

56. Aziz, M. A., Khan, A. H., Adnan, M. \& Ullah, H. Traditional uses of medicinal plants used by Indigenous communities for veterinary practices at Bajaur Agency, Pakistan. J. Ethnobiol. Ethnomed. 14, 1-18 (2018).

57. Xu, Q. et al. The quest for modernisation of traditional Chinese medicine. BMC Complement. Altern. Med. 13, (2013).

58. Kalkidan Mamo, W., Fufa Abunna, K. \& Yonas Tolosa, R. A review on nanotechnology and its application in modern veterinary science. Int. J. Nanomater. Nanotechnol. Nanomedicine 7, 026-031 (2021).

59. Machado, M. et al. Microemulsion systems to enhance the transdermal permeation of 
ivermectin in dogs: A preliminary in vitro

study. Res. Vet. Sci. 133, 31-38 (2020). 